\title{
PERANCANGAN SISTEM PAKAR DIAGNOSA PENYAKIT PADA BAYI MENGGUNAKAN METODE DEMPSTER SHAFER
}

\author{
Isminarni Rahayu ${ }^{1}$, Salman Topiq ${ }^{2}$, Sari Susanti ${ }^{3}$ \\ 1 Universitas Adhirajasa Reswara Sanjaya \\ e-mail: isminarni2903@gmail.com \\ ${ }^{2}$ Universitas Adhirajasa Reswara Sanjaya \\ e-mail: salman@ars.ac.id \\ ${ }^{3}$ Universitas Adhirajasa Reswara Sanjaya \\ e-mail: sarisusanti@ars.ac.id
}

\begin{abstract}
Abstrak
Lemahnya ketahanan tubuh bayi membuat bayi sangat rentang terhadap kuman, bakteri dan penyakit. Bayi mengalami kesulitan dalam menjelaskan keluhannya, oleh karena itu orang tua diharapkan dapat menangkap setiap bahasa tubuh dari anak mereka. Pada umumnya, apabila anak mengalami gangguan kesehatan maka orang tua akan memeriksa ketempat pelayanan kesehatan dan berkonsultasi dengan tenaga kesehatan ahli dalam bidangnya, tetapi terkadang terdapat hambatan seperti terbatasnya jam kerja (praktek). Maka dalam penelitian ini dibuatkan sebuah alat bantu berupa sistem pakar berbasis android untuk mendiagnosa penyakit pada bayi menggunakan metode dempster shafer. Metode Dempster Shafer merupakan teori matematika untuk membuktikan sebuah hipotesa berdasarkan fungsi kepercayaan dan pemikiran yang masuk akal,yang berguna untuk mengkombinasikan potongan informasi yang terpisah atau bukti untuk mengkonkulasi kemungkinan dari peristiwa. Pada saat ini keberadaan platform android sangat populer dikalangan pengguna smartphone. Oleh sebab itu dibuatlah aplikasi sistem pakar berbasis android yang berguna untuk mendiagnosa penyakit pada bayi untuk membantu orang tua mendapatkan informasi tentang penyakit yang dialami anaknya.
\end{abstract}

Kata Kunci: Sistem Pakar, Dempster Shafer, Penyakit, Bayi

\begin{abstract}
The weak resistance of the baby's body makes the baby very vulnerable to germs, bacteria and diseases. Babies have difficulty in explaining their complaints, so parents are expected to be able to understand every body language of their child. If a child has a health problem, the parents will generally visit the health department and consult with an expert in their field, but sometimes there are obstacles such as limited working hours (practice). So, in this study, a tool is created in the form of an Android-based expert system to diagnose illnesses in infants using the dampster shafer method. The Dempster Shafer Method is a mathematical theory for proving a hypothesis based on a function of belief and reasoning, which is useful for combining individual pieces of information or evidence to infer the probability of events. At present, the existence of the Android platform is very popular among smartphone users. Therefore, an Android-based expert system application has been created that is useful for diagnosing illnesses in infants to help parents learn about the illnesses their children are experiencing.
\end{abstract}

Keywords: Expert System, Dempster Shafer, Disease, Baby 


\section{Pendahuluan}

Di Indonesia, masalah kesehatan masih menjadi masalah utama dan menjadi perhatian serius dari pemerintah. Salah satu indikator yang menunjukkan derajat kesehatan di suatu masyarakat adalah Angka Kematian Bayi (AKB) (Wulandari et al., 2018). Indonesia masih menempati peringkat kedua AKB tertinggi di ASEAN pada tahun 2017 (Utama \& Hidayat, 2020). Anak (bayi) perlu diawasi kesehatannya karena masih lemah daya tahan tubuh membuat bayi menjadi rentan terhadap kuman, bakteri ataupun penyakit. Bayi merasa kesulitan untuk menjelaskan keluhannya, berdasarkan hal tersebut orang tua diharapkan mampu memahami bahasa tubuh yang ditunjukan oleh anaknya. Umumnya, Ketika anak telah mengalami gangguan pada Kesehatan tubuhnya maka orang tua akan memeriksa ketempat pelayanan Kesehatan. Melakukan konsultasi dengan semua tenaga kesehatan yang ahli. Pada pelaksanaanya tak jarang terjadi hambatan contohnya terbatasnya jam kerja atau waktu (praktek). Berdasarkan masalah tersebut perlu dibuat sebuah aplikasi. Aplikasi diperuntukan untuk membantu orang tua sehingga dapat mengenali gejalagejala suatu penyakit serta menyimpulkannya, harapannya orang tua dapat memberikan pertolongan berdasarkan hasil diagnosis tersebut (Syaifuddin et al., 2014).

Sistem pakar (expert system) merupakan sistem yang mengadopsi pola pikir dari pakar untuk selanjutnya diterapkan ke dalam sebuah software, supaya komputer dapat menyelesaikan permasalahan seperti halnya yang sudah terbiasa dilakukan oleh ahli atau pakar (Hafizh \& Putra, 2018). Metode Dempster Shafer merupakan salah satu dari metode sistem pakar. Metode Dempster Shafer ini termasuk bagian dari cabang ilmu matematika dan biasa digunakan untuk menghitung probabilitas (Kanggeraldo et al., 2018). Metode ini menunjukkan suatu cara untuk memberikan bobot keyakinan sesuai fakta yang dikumpulkan kemudian mengkombinasikan potongan informasi yang terpisah dan mengkalkulasikan kemungkinan dari suatu peristiwa. Logika ini digunakan untuk menghitung inputan data yang dilakukan oleh pasien guna mendapatkan persentase keakuratan hasil diagnosis (Hasibuan \& Batubara, 2019).
Dari penelitian yang dilakuan oleh Jeffri Rizky Maulana, Fitriyadi , Ratna Fitriani pada tahun 2016 yang berjudul Sistem Pakar Diagnosa Penyakit Tanaman Karet Dengan Metode Dempster Shafer menghasilkan akurasi $100 \%$. Selain itu, penelitian sebelumnya yang telah dilakukan oleh (Kanggeraldo et al., 2018) yang berjudul Sistem Pakar Untuk Mendiagnosis Penyakit Stroke Hemoragik dan Iskemik Menggunakan Metode Dempster Shafer menghasilkan akurasi sebesar 97\%. Dari kedua penelitian tersebut metode Dempster Shafer dapat menghasilkan data yang akurat. Penerapan metode Dempster Shafer juga pernah digunakan pada penelitian (Mubarok, Susanti \& Imelia, 2020). Hal tersebut menjadi rujukan untuk penelitian ini.

\section{Metode Penelitian}

\section{a. Metode Dempster Shafer}

Secara umum, teori Dempster Shafer ditulis dalam suatu interval (Ayu \& Hasibuan, 2017) :

1. Belief (Bel) merupakan ukuran kekuatan evidence (bukti) dalam mendukung suatu himpunan proposisi. Jika bernilai 0 maka mengindikasikan bahwa tidak ada evidence, dan jika bernilai 1 menunjukkan adanya kepastian.

2. Plausability $(\mathrm{PI})$ dinotasikan sebagai:

$$
\mathrm{PI}(\mathrm{s})=1-\operatorname{Bel}(\neg \mathrm{s})
$$

Plausability bernilai 0 sampai 1 . Jika yakin $\neg \mathrm{s}$, maka dapat dikatakan bahwa $\operatorname{Bel}(\neg \mathrm{S})=1$, dan $\mathrm{PI}(\neg \mathrm{s})=0$. Teorema Dempster Shafer mengenal adanya frame of discernment yang dinotasikan dengan $\theta$. Frame merupakan semesta pembicaraan dari sekumpulan hipotesis. Tujuan adalah membangkitkan kepercayaan elemenelemen $\theta$. Tidak semua evidence secara langsung mendukung tiap-tiap elemen. Sebagai contoh, panas mungkin hanya mendukung $\{F, D, B\}$ Untuk itu perlu adanya probabilitas densitas $(\mathrm{m})$. Nilai $\mathrm{m}$ tidak hanya mendefinisikan elemen-elemen $\theta$ saja, namun juga semua subset. Sehingga jika $\theta$ berisi $\mathrm{n}$ elemen, maka subset dari $\theta$ semua berjumlah $2 \mathrm{n}$. Nilai yang dihasilkan dari teori ini berupa persentase tiap elemen-elemen $\theta$, dan juga semua subset. Makin rendah persentase frame of discernment menggambarkan makin baik tingkat pemahaman pasien dalam materi tersebut.

Penilaian diberikan kepada elemenelemen berdasarkan hasil persentasi ini: 


$$
\mathrm{m}_{3}(\mathrm{Z})=\frac{\Sigma x \cap y=\mathrm{z} m 1(x) \cdot \mathrm{m} 2(y)}{1-\Sigma x \cap y=\emptyset \mathrm{m} 1(\mathrm{x}) \cdot \mathrm{m} 2(\mathrm{y})}
$$

Gambar 1. Rumus Dempster Shafer Sumber : (Ayu \& Hasibuan, 2017)

Dimana :

$\mathrm{m} 3(\mathrm{Z})=$ mass function dari avidence $(\mathrm{Z})$ $\mathrm{m} 1(\mathrm{X})=$ mass function dari evidence $(\mathrm{X})$, yang diperoleh dari nilai keyakinan suatu evidence dikalikan dengan nilai disbelief dari evidence tersebut.

$\mathrm{m} 2(\mathrm{Y})=$ mass function dari evidence $(\mathrm{Y})$, yang diperoleh dari nilai keyakinan suatu evidence dikalikan dengan nilai disbelief dari evidence tersebut.

\section{a. Pengumpulan Data}

Pengumpulan Data Pakar Pengumpulan data pakar disini berisikan tentang informasi untuk diagnosis awal penyakit pada bayi yang dapat disimpulkan dari beberapa faktor, yaitu penyebab dan gejala kemudian akan diolah sehingga menghasilkan sebuah keputusan berupa penyakit yang diderita serta saran asupan makanan sesuai kebutuhan bayi. Data tersebut diperoleh dari wawancara, pengisian, buku dan artikel yang telah divalidasi dan dikonsultasikan kepada pakar bidan yang berada di Puskesmas Griya Antapani. Objek pakar yaitu lbu Siti Wiarsih yang bekerja sebagai bidan di Puskesmas Griya Antapani.

b. Basis pengetahuan

Nilai kepercayaan atau densitas merupakan nilai kemungkinan dari sebuah gejala terhadap suatu penyakit. Gejala dan nilai densitas diperoleh dari hasil wawancara terhadap pakar yang merupakan seorang pakar Siti Wiarsih yang merupakan bidan yang berada di Puskesmas Griya Antapani. Berdasarkan hasil wawancara, terdapat 6 penyakit dengan 17 gejala fisik yang dapat terlihat.

\begin{tabular}{|c|l|c|}
\multicolumn{1}{|c}{ Tabel 1. Data Dari Pakar } \\
\hline \multirow{1}{*}{$\begin{array}{c}\text { Nama } \\
\text { Penyakit }\end{array}$} & \multicolumn{1}{|c|}{ Nama Gejala } & Nilai \\
\hline \multirow{5}{*}{ Diare } & $\begin{array}{l}\text { Feses yang } \\
\text { dihasilkan banyak } \\
\text { dan cair }\end{array}$ & \\
\cline { 2 - 3 } & Muntah-muntah & 0.8 \\
\cline { 2 - 3 } & Bayi menjadi rewel & 0.4 \\
\cline { 2 - 3 } & Bayi kelihatan lemas & 0.6 \\
\hline
\end{tabular}

\begin{tabular}{|c|c|c|}
\hline & $\begin{array}{l}\text { Mulut dan bibir pecah } \\
\text { pecah }\end{array}$ & 0.2 \\
\hline \multirow{6}{*}{ Campak } & Bayi kelihatan lemas & 0.6 \\
\hline & Bayi demam & 0.8 \\
\hline & $\begin{array}{l}\text { Ruam kemerahan di } \\
\text { wajah }\end{array}$ & 0.6 \\
\hline & $\begin{array}{l}\text { Bintik putih pada area } \\
\text { mulut }\end{array}$ & 0.4 \\
\hline & $\begin{array}{lr}\text { Mata } & \text { merah dan } \\
\text { sensitif } & \text { terhadap } \\
\text { cahaya } & \\
\end{array}$ & 0.6 \\
\hline & $\begin{array}{ll}\text { Nafsu } & \text { makan } \\
\text { menurun }\end{array}$ & 0.6 \\
\hline \multirow{3}{*}{$\begin{array}{l}\text { Ruam } \\
\text { Popok }\end{array}$} & $\begin{array}{l}\text { Bercak kemerahan } \\
\text { pada bagian area } \\
\text { bokong, paha dan } \\
\text { alat kelamin }\end{array}$ & 0.8 \\
\hline & Bayi menjadi rewel & 0.8 \\
\hline & $\begin{array}{l}\text { Kulit bayi terasa } \\
\text { panas saat disentuh }\end{array}$ & 0.8 \\
\hline \multirow{5}{*}{ Demam } & $\begin{array}{l}\text { Nafsu } \\
\text { menurun }\end{array}$ & 0.6 \\
\hline & $\begin{array}{l}\text { Suhu tubuh bayi } \\
\text { diatas } 37,6\end{array}$ & 0.8 \\
\hline & Bayi menjadi rewel & 0.6 \\
\hline & Muntah-muntah & 0.4 \\
\hline & Bayi kelihatan lemas & 0.4 \\
\hline \multirow{5}{*}{$\begin{array}{l}\text { Batuk } \\
\text { Pilek }\end{array}$} & Batuk- batuk & 0.8 \\
\hline & $\begin{array}{l}\text { Hidung bayi meler } \\
\text { atau tersumbat }\end{array}$ & 0.8 \\
\hline & Bayi menjadi rewel & 0.6 \\
\hline & Bayi demam & 0.6 \\
\hline & Bayi kelihatan lemas & 0.4 \\
\hline \multirow{3}{*}{ Dermatitis } & $\begin{array}{l}\text { Bintik kemerahan } \\
\text { pada kulit bayi }\end{array}$ & 0.8 \\
\hline & $\begin{array}{l}\text { Bayi menjadi } \\
\text { rewel }\end{array}$ & 0.6 \\
\hline & Gatal-gatal & 0.8 \\
\hline
\end{tabular}

Tabel 2. Data Penyakit Pada Bayi

\begin{tabular}{|c|c|}
\hline Kode Penyakit & Nama Penyakit \\
\hline P1 & Diare \\
\hline P2 & Campak \\
\hline P3 & Ruam Popok \\
\hline P4 & Demam \\
\hline P5 & Batuk Pilek \\
\hline P6 & Dermatitis \\
\hline
\end{tabular}

Tabel 3. Daftar Gejala Dengan Nilai Densitas 


\begin{tabular}{|c|c|c|c|}
\hline Kode & Nama Gejala & $\begin{array}{l}\text { Nilai } \\
\text { Bel }\end{array}$ & $\begin{array}{l}\text { Nilai } \\
\text { PI }\end{array}$ \\
\hline G01 & $\begin{array}{l}\text { Feses yang dihasilkan } \\
\text { banyak dan cair }\end{array}$ & 0.8 & 0.2 \\
\hline G02 & Muntah-muntah & 0.4 & 0.6 \\
\hline G03 & Bayi menjadi rewel & 0.6 & 0.4 \\
\hline G04 & Bayi kelihatan lemas & 0.5 & 0.5 \\
\hline G05 & $\begin{array}{l}\text { Mulut dan bibir pecah } \\
\text { pecah }\end{array}$ & 0.2 & 0.8 \\
\hline G06 & Bayi demam & 0.7 & 0.3 \\
\hline G07 & $\begin{array}{l}\text { Ruam kemerahan di } \\
\text { wajah }\end{array}$ & 0.6 & 0.4 \\
\hline G08 & $\begin{array}{l}\text { Bintik putih pada area } \\
\text { mulut }\end{array}$ & 0.4 & 0.6 \\
\hline G09 & $\begin{array}{lr}\text { Mata } & \text { merah dan } \\
\text { sensitif } & \text { terhadap } \\
\text { cahaya } & \\
\end{array}$ & 0.6 & 0.4 \\
\hline G10 & Nafsu makan menurun & 0.6 & 0.4 \\
\hline G11 & $\begin{array}{l}\text { Bercak kemerahan } \\
\text { pada bagian area } \\
\text { bokong, paha dan alat } \\
\text { kelamin }\end{array}$ & 0.8 & 0.2 \\
\hline G12 & $\begin{array}{l}\text { Kulit bayi terasa panas } \\
\text { saat disentuh }\end{array}$ & 0.8 & 0.2 \\
\hline G13 & $\begin{array}{l}\text { Suhu tubuh bayi diatas } \\
37,6\end{array}$ & 0.8 & 0.2 \\
\hline G14 & Batuk- batuk & 0.8 & 0.2 \\
\hline G15 & $\begin{array}{l}\text { Hidung Bayi meler atau } \\
\text { tersumbat }\end{array}$ & 0.8 & 0.2 \\
\hline G16 & $\begin{array}{l}\text { Bintik kemerahan pada } \\
\text { kulit bayi }\end{array}$ & 0.8 & 0.2 \\
\hline G17 & Gatal- gatal & 0.6 & 0.4 \\
\hline
\end{tabular}

c. Rule-rule Pada Pakar

Algoritma yang digunakan dalam pencarian keputusan menggunakan metode Dempster Shafer yang mempresentasikan pengetahuan yang digunakan dalam sistem pakar. Metode ini ditulis dalam bentuk pengujian IF-THEN.

Dibawah ini pseudocode untuk rancangan algoritma Dempster Shafer dalam mengimplementasikan aplikasi sistem pakar ini, berikut rule penyelesaiannya:

1. Rule 1

If Feses yang dihasilkan banyak dan cair

And Muntah-muntah

And Bayi menjadi rewel

And Bayi keliatan lemas

And Mulut dan bibir bayi pecah-pecah
Then Diare

2. Rule 2

If Bayi keliatan lemas

And Bayi demam

And Ruam kemerahan di wajah

And Bintik putih pada area mulut

And Mata merah dan sensitive

terhadap cahaya

And Nafsu makan menurun

Then Campak

3. Rule 3

If Bercak kemerahan pada area

bokong, paha dan alat kelamin

And Bayi menjadi rewel

And Kulit bayi terasa panas saat

disentuh

Then Ruam Popok

4. Rule 4

If Nafsu makan menurun

And Suhu tubuh bayi diatas 37,6

And Bayi menjadi rewel

And Muntah-muntah

And Bayi keliatan lemas

Then Demam

5. Rule 5

If Batuk-batuk

And Hidung bayi meler atau tersumbat

And Bayi menjadi rewel

And Bayi demam

And Bayi keliatan lemas

Then Batuk Pilek

6. Rule 6

If Bintik kemerahan pada kulit

And Bayi menjadi rewel

And Gatal-gatal

Then Dermatitis

\section{Hasil dan Pembahasan}

\subsection{Implementasi}

Berikut ini implementasi dari aplikasi sistem pakar diagnosa penyakit pada bayi menggunakan metode dempster shafer:

\section{a. Tampilan Splash Screen}

Ketika membuka aplikasi, user akan melihat tampilan splash screen terlebih dahulu selama 3 detik yang berupa gambar logo dan nama aplikasi seperti gambar berikut: 


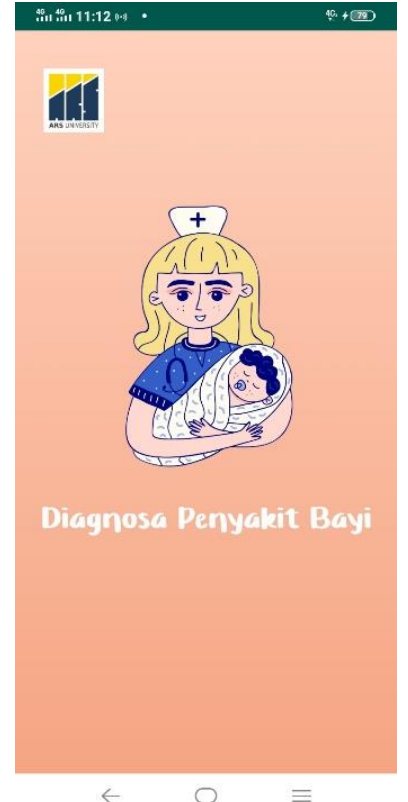

\section{Gambar 2. Tampilan Splash Screen}

\section{b. Tampilan Menu Utama}

Pada menu utama, user akan melihat tampilan menu utama yang berisi 7 icon menu yang berupa image button untuk dipilih, diantaranya menu cek penyakit, menu list penyakit, menu artikel bayi, menu asupan, menu stimulasi, bantuan dan menu profil seperti gambar berikut:

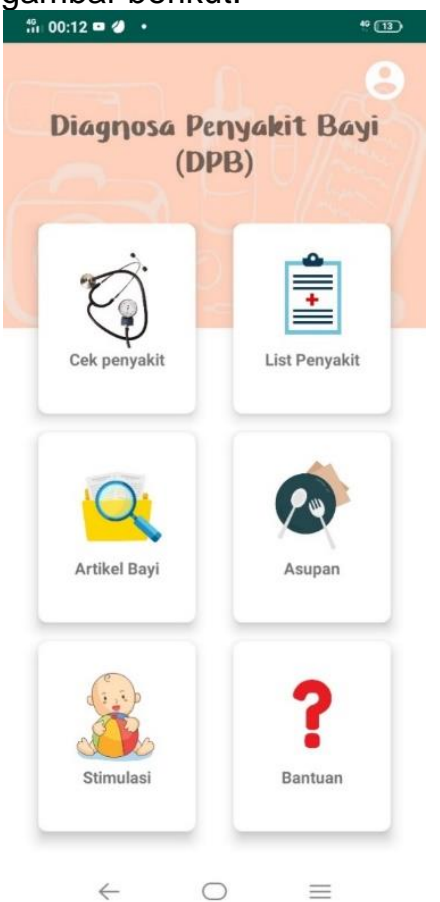

Gambar 3. Tampilan Menu Utama

\section{c. Tampilan Menu Cek Penyakit}

Pada menu cek penyakit, user akan melihat gejala-gejala penyakit yang berupa checkbox untuk dipilih dan tombol hasil untuk mengetahui hasil diagnosis penyakit beserta cara penanganannya seperti gambar berikut:

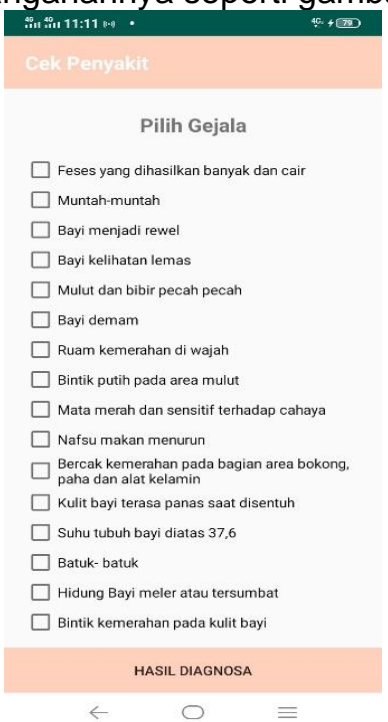

Gambar 4. Tampilan Menu Cek Penyakit

\section{d. Tampilan Hasil Diagnosis} Penyakit

Pada menu cek penyakit user memilih gejala dan menekan button hasil diagnosa, user akan melihat tampilan hasil diagnosis yang berupa persentase kemungkinan dan ketidakmungkinan penyakit serta cara penanganannya. Untuk dapat mengakses informasi penanganan, user harus terhubung dengan internet karena data diambil dari database. Setelah melihat hasil diagnosis penyakit, user dapat memilih tombol cek lagi untuk kembali mendiagnosis penyakit dan tombol selesai untuk keluar dari menu cek penyakit seperti gambar berikut:

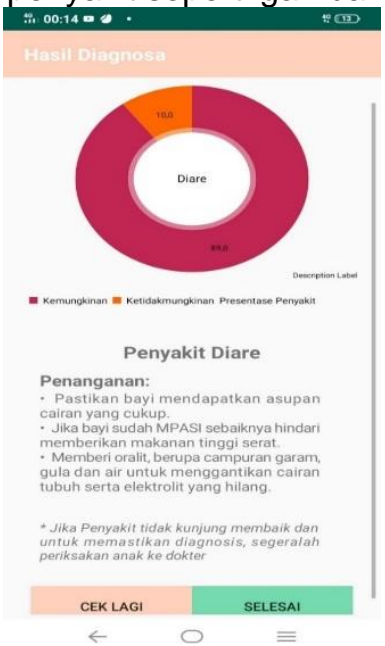

Gambar 5. Tampilan Hasil Diagnosa Penyakit 


\section{e. Tampilan Menu List Penyakit}

Pada menu list penyakit, user akan melihat tampilan yang berupa 6 list penyakit yang bisa dipilih untuk mengetahui informasi penyakit tersebut. Untuk dapat mengakses list penyakit ini, user harus terhubung dengan internet karena data disimpan di database. List penyakit ini memiliki tampilan berupa gambar dan nama penyakit seperti gambar berikut:

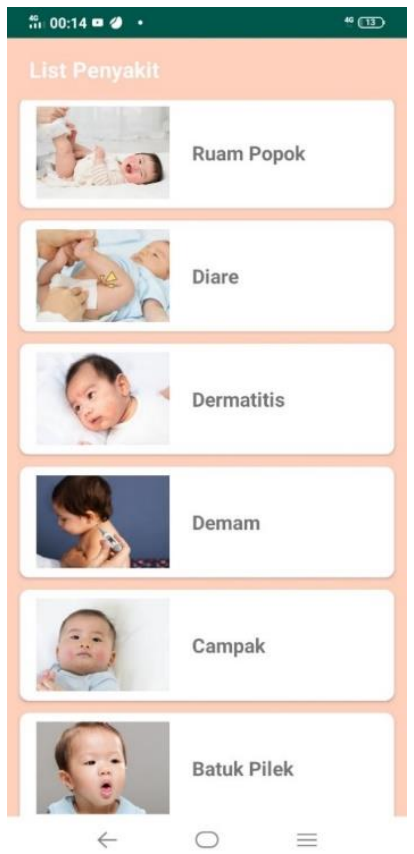

Gambar 6. Tampilan Menu List Penyakit

\section{f. Tampilan Info Penyakit}

Pada menu list penyakit user menekan nama penyakit yang ingin dipilih, kemudian user akan melihat tampilan info penyakit yang dipilih. Untuk dapat mengakses info penyakit ini, user harus terhubung dengan internet karena data diambil dari database. Tampilan info penyakit ini berupa gambar dan informasi penjelasan dari penyakit beserta cara penanganannya seperti gambar berikut:

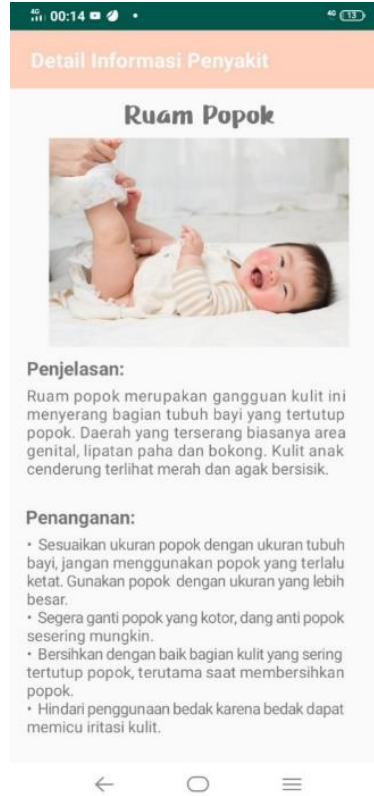

Gambar 7. Tampilan Menu Info Penyakit

\section{g. Tampilan Menu Artikel Bayi}

Pada menu artikel bayi, user akan melihat tampilan daftar artikel yang bisa dipilih untuk mengetahui informasi dari artikel tersebut. Untuk dapat mengakses artikel bayi ini, user harus terhubung dengan internet karena data disimpan di database. Artikel bayi ini memiliki tampilan berupa gambar dan judul artikel seperti gambar berikut:

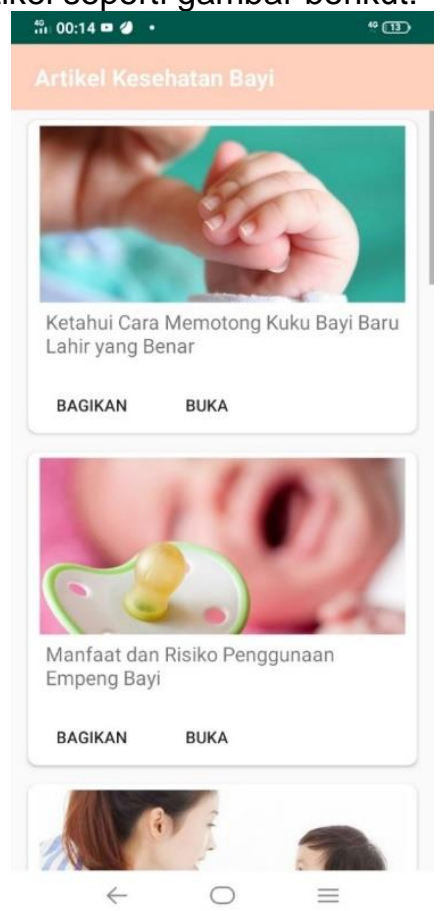

Gambar 8. Tampilan Menu Artikel Bayi 


\section{h. Tampilan Buka Artikel}

Pada menu artikel bayi user menekan button buka maka user akan dialihkan ke situs website untuk melihat tampilan detail artikel. Untuk dapat mengakses artikel ini, user harus terhubung dengan internet karena data disimpan di database. Detail artikel ini memiliki tampilan berupa artikel dari situs website seperti gambar berikut:

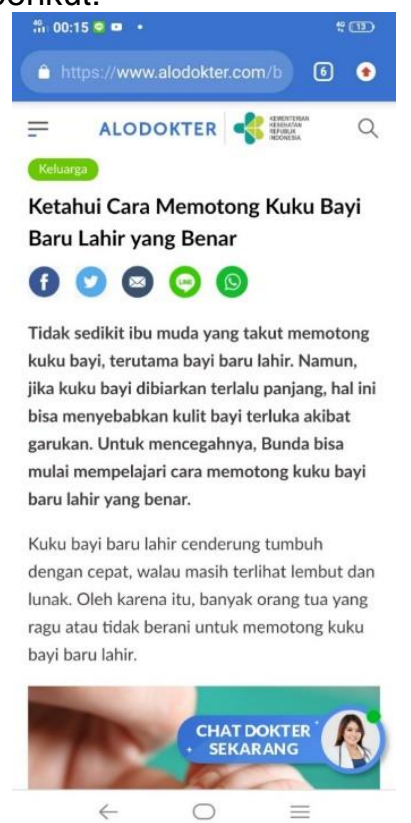

Gambar 9. Tampilan Detail Artikel

i. Tampilan Share Artikel

Pada menu artikel bayi user menekan share maka user akan diberi pilihan send to. Untuk dapat mengaksesnya user harus terhubung dengan internet karena data disimpan di database. share artikel ini memiliki tampilan seperti gambar berikut:

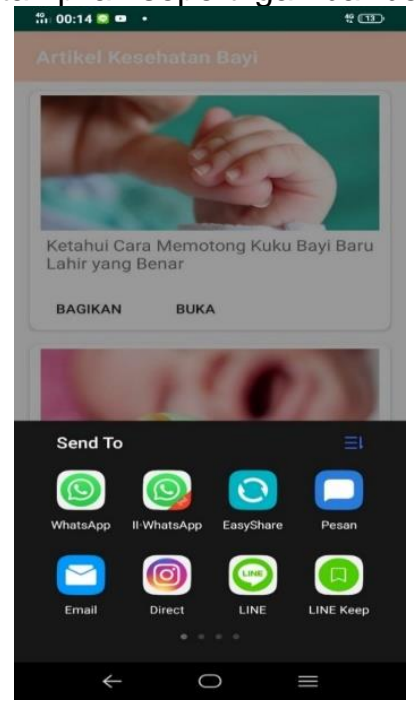

Gambar 10. Tampilan Share Artikel

\section{j. Tampilan Menu Asupan Makan}

Pada menu asupan makan, user akan melihat informasi asupan makan yang baik untuk bayi. Menu asupan ini memiliki tampilan seperti gambar berikut:

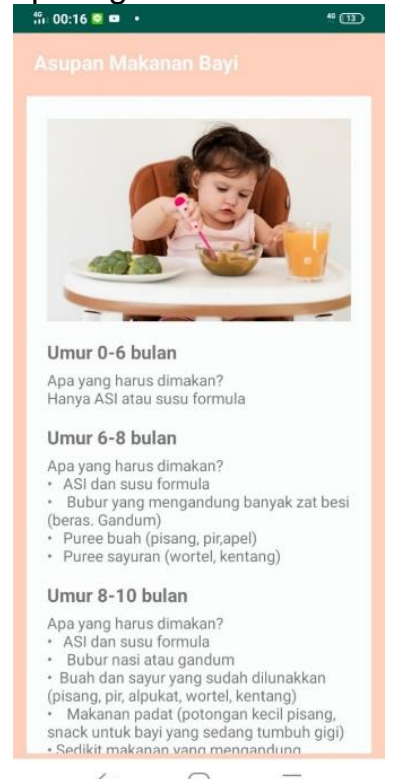

\section{Gambar 11. Tampilan Menu Asupan k. Tampilan Menu Stimulasi}

Pada menu stimulasi, user akan melihat tampilan yang berupa list stimulasi berdasarkan umur bayi yang bisa dipilih untuk mengetahui informasi stimulasi bayi tersebut. Untuk dapat mengakses stimulasi ini, user harus terhubung dengan internet karena data disimpan di database. Menu stimulasi ini memiliki tampilan seperti gambar berikut:

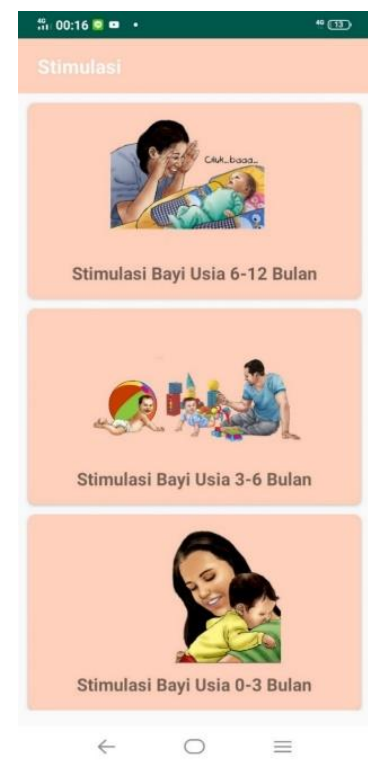

Gambar 12. Tampilan Menu Stimulasi 


\section{Tampilan Detail Stimulasi}

Pada menu list stimulasi user menekan stimulasi yang ingin dipilih, kemudian user akan melihat tampilan Detail yang dipilih. Untuk dapat mengakses detail stimulasi ini, user harus terhubung dengan internet karena data diambil dari database. detail stimulasi ini memiliki tampilan seperti gambar berikut:

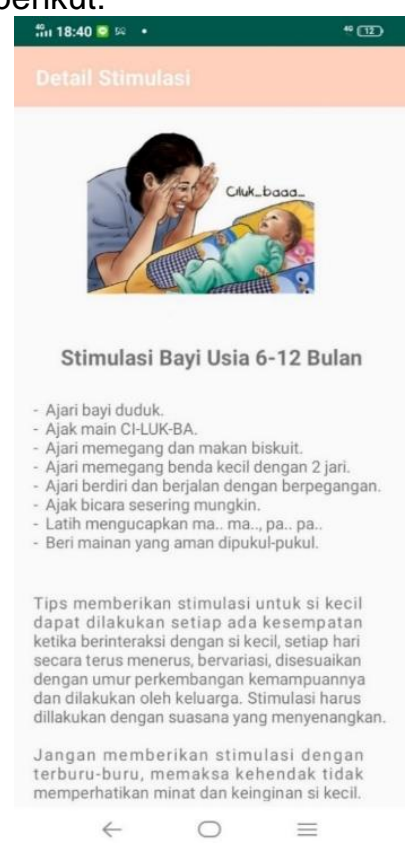

Gambar 13. Tampilan Detail Stimulasi

\section{m. Tampilan Menu Bantuan}

Pada menu bantuan, user akan melihat tampilan yang berupa informasi tentang aplikasi dan penjelasan dari setiap menu yang ada di aplikasi. Menu bantuan ini memiliki tampilan seperti gambar berikut:

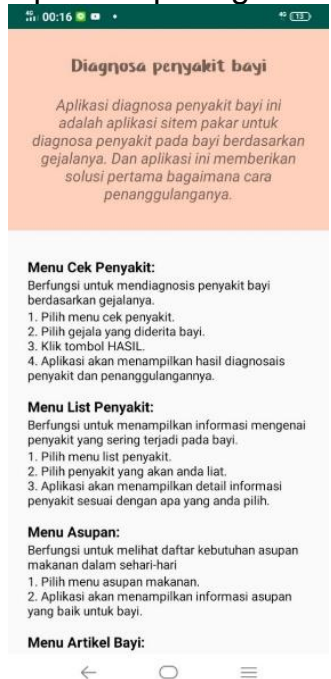

Gambar 14. Tampilan Menu Bantuan

\section{n. Tampilan Menu profil}

Pada menu profil, pengguna dapat melihat informasi biodata dan kontak dari pembuat aplikasi. Menu profil ini memiliki tampilan seperti gambar berikut:

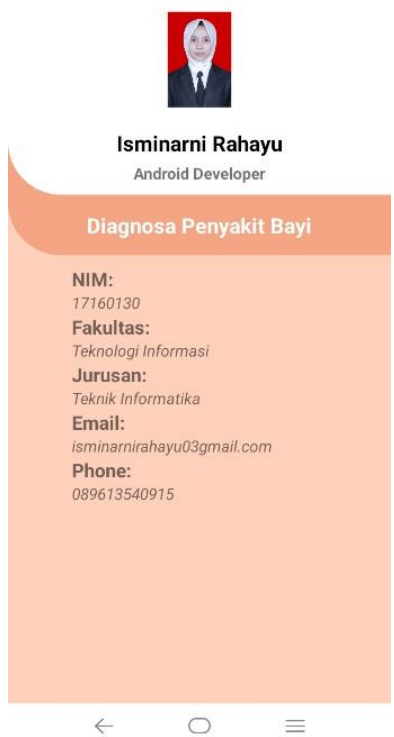

Gambar 15. Tampilan Menu Profil

\subsection{Testing}

Pengujian perlu dilakukan terhadap aplikasi untuk dapat diketahui apakah aplikasi yang dibuat berjalan sesuai dengan rencana atau tidak. Aplikasi ini menggunakan pengujian alpha dengan metode black box yang berfokus pada persyaratan fungsional perangkat lunak.

\section{A. Hasil Pengujian Alpha Dengan Metode Black box}

Berikut hasil pengujian aplikasi sistem pakar diagnosis penyakit pada bayi menggunakan pengujian alpha dengan metode black box:

Tabel 4. Hasil Pengujian Alpha Dengan Metode Black Box

\begin{tabular}{|l|l|l|l|l|}
\hline No & $\begin{array}{c}\text { Nama } \\
\text { Fungsi } \\
\text { Yang Diuji }\end{array}$ & $\begin{array}{l}\text { Skenario } \\
\text { Pengujian }\end{array}$ & $\begin{array}{c}\text { Hasil Yang } \\
\text { Diharapkan }\end{array}$ & $\begin{array}{c}\text { Hasil } \\
\text { Penguji } \\
\text { an }\end{array}$ \\
\hline 1. & $\begin{array}{l}\text { Tampilan } \\
\text { Splash }\end{array}$ & $\begin{array}{l}\text { Ketika } \\
\text { membuka } \\
\text { aplikasi }\end{array}$ & $\begin{array}{l}\text { Menampilkan } \\
\text { gambar splash } \\
\text { screen }\end{array}$ & Berhasil \\
\hline 2. & Menu Utama & $\begin{array}{l}\text { Ketika } \\
\text { tampilan } \\
\text { splash } \\
\text { screen } \\
\text { selesai }\end{array}$ & $\begin{array}{l}\text { Menampilkan } \\
\text { menu utama } \\
\text { yang berisi 7 } \\
\text { icon menu }\end{array}$ & Berhasil \\
\hline
\end{tabular}




\begin{tabular}{|c|c|c|c|c|}
\hline \multirow[t]{2}{*}{3.} & \multirow[t]{2}{*}{$\begin{array}{l}\text { Menu Cek } \\
\text { Penyakit }\end{array}$} & \multirow{2}{*}{$\begin{array}{l}\text { Menekan } \\
\text { icon menu } \\
\text { cek } \\
\text { penyakit, } \\
\text { memilih } \\
\text { gejala, } \\
\text { menekan } \\
\text { tombol } \\
\text { Hasil }\end{array}$} & $\begin{array}{l}\text { Menampilkan } \\
\text { gejala-gejala } \\
\text { penyakit yang } \\
\text { berupa } \\
\text { checkbox }\end{array}$ & Berhasil \\
\hline & & & Tombol Hasil & Berhasil \\
\hline \multirow[t]{3}{*}{4.} & \multirow[t]{3}{*}{$\begin{array}{l}\text { Hasil } \\
\text { Diagnosis } \\
\text { Penyakit }\end{array}$} & \multirow[t]{3}{*}{\begin{tabular}{ll}
\multicolumn{2}{l}{ Menekan } \\
tombol cek \\
lagi \\
tombol dan \\
selesai
\end{tabular}} & $\begin{array}{l}\text { Menampilkan } \\
\text { hasil diagnosis } \\
\text { penyakit dan } \\
\text { cara } \\
\text { penangananny } \\
\text { a }\end{array}$ & Berhasil \\
\hline & & & $\begin{array}{l}\text { Tombol Cek } \\
\text { Lagi }\end{array}$ & Berhasil \\
\hline & & & $\begin{array}{l}\text { Tombol } \\
\text { Selesai }\end{array}$ & Berhasil \\
\hline 5. & $\begin{array}{l}\text { Menu List } \\
\text { Penyakit }\end{array}$ & $\begin{array}{l}\text { Menekan } \\
\text { icon menu } \\
\text { list penyakit, } \\
\text { memilih } \\
\text { penyakit }\end{array}$ & $\begin{array}{l}\text { Menampilkan } \\
\text { list daftar } \\
\text { penyakit yang } \\
\text { bisa dipilih }\end{array}$ & Berhasil \\
\hline 6. & Info Penyakit & $\begin{array}{l}\text { Memilih } \\
\text { daftar } \\
\text { penyakit } \\
\text { yang ingin } \\
\text { dilihat }\end{array}$ & $\begin{array}{l}\text { Menampilkan } \\
\text { informasi } \\
\text { penyakit } \\
\text { berupa } \\
\text { gambar, } \\
\text { pengertian dan } \\
\text { pencegahanny } \\
\text { a }\end{array}$ & Berhasil \\
\hline 7. & $\begin{array}{l}\text { Menu } \\
\text { Artikel Bayi }\end{array}$ & $\begin{array}{l}\text { Menekan } \\
\text { icon menu } \\
\text { artikel bayi, } \\
\text { memilih } \\
\text { daftar artikel }\end{array}$ & $\begin{array}{l}\text { Menampilkan } \\
\text { daftar artikel } \\
\text { yang bisa } \\
\text { dipilih }\end{array}$ & Berhasil \\
\hline 8. & $\begin{array}{l}\text { Detail } \\
\text { Artikel }\end{array}$ & $\begin{array}{l}\text { Memilih } \\
\text { mengklik list } \\
\text { artikel yang } \\
\text { ingin dilihat } \\
\text { dan klik } \\
\text { button buka }\end{array}$ & $\begin{array}{l}\text { Menampilkan } \\
\text { informasi } \\
\text { berupa artikel } \\
\text { dari website } \\
\text { seputar } \\
\text { kesehatan bayi }\end{array}$ & Berhasil \\
\hline 9. & $\begin{array}{l}\text { Share } \\
\text { Artikel }\end{array}$ & $\begin{array}{l}\text { Memilih list } \\
\text { artikel yang } \\
\text { ingin dilihat } \\
\text { dan klik } \\
\text { button share }\end{array}$ & $\begin{array}{l}\text { Menampilkan } \\
\text { pilihan send to } \\
\text { untuk } \\
\text { mengirim lewat } \\
\text { apa }\end{array}$ & Berhasil \\
\hline 10. & $\begin{array}{l}\text { Menu } \\
\text { Asupan }\end{array}$ & $\begin{array}{l}\text { Menekan } \\
\text { icon menu } \\
\text { asupan }\end{array}$ & $\begin{array}{l}\text { Menampilkan } \\
\text { informasi } \\
\text { asupan } \\
\text { makanan yang } \\
\text { baik untuk bayi }\end{array}$ & Berhas \\
\hline
\end{tabular}

\begin{tabular}{|c|c|c|c|c|}
\hline 10. & $\begin{array}{l}\text { Menu } \\
\text { bantuan }\end{array}$ & $\begin{array}{l}\text { Menekan } \\
\text { icon menu } \\
\text { bantuan }\end{array}$ & $\begin{array}{l}\text { Menampilkan } \\
\text { informasi } \\
\text { tentang } \\
\text { aplikasi dan } \\
\text { penjelasan dari } \\
\text { setiap menu } \\
\text { yang ada di } \\
\text { aplikasi }\end{array}$ & Berhasil \\
\hline 13. & Profil & $\begin{array}{l}\text { Menekan } \\
\text { tombol profil }\end{array}$ & $\begin{array}{l}\text { Menampilkan } \\
\text { informasi } \\
\text { pembuat } \\
\text { aplikasi }\end{array}$ & Berhasil \\
\hline
\end{tabular}

metode black box yang telah dilakukan, maka ditarik kesimpulan bahwa dalam aplikasi sistem pakar diagnosis penyakit pada bayi menggunakan metode dempster shafer tidak terdapat kesalahan proses dan secara fungsional telah berjalan dengan baik sesuai apa yang diharapkan.

B. Pengujian Sistem Dengan Pakar

Pengujian dilakukan oleh seorang bidan untuk mengetahui kesesuaian hasil diagnosis, pakar tersebut melakukan diagnosis dari gejala-gejala yang ada. Pengujian ini dilakukan dengan mencocokkan hasil dari diagnosis aplikasi sistem pakar dan hasil diagnosis pakar sehingga hasil yang didapatkan seperti berikut:

Tabel 5. Hasil Pengujian Sistem Dengan

\begin{tabular}{|c|c|c|c|c|}
\hline \multicolumn{5}{|c|}{ Pakar } \\
\hline No & Gejala & $\begin{array}{c}\text { Hasil } \\
\text { Sistem }\end{array}$ & Hasil Pakar & Ket \\
\hline \multirow{5}{*}{1.} & $\begin{array}{l}\text { Feses yang } \\
\text { dihasilkan banyak } \\
\text { dan cair }\end{array}$ & \multirow[t]{5}{*}{$\begin{array}{r}\text { Diare } \\
97 \%\end{array}$} & \multirow[t]{5}{*}{$\begin{array}{l}\text { Diare } \\
80-90 \%\end{array}$} & Valid \\
\hline & Muntah-muntah & & & Valid \\
\hline & Bayi menjadi rewel & & & Valid \\
\hline & $\begin{array}{l}\text { Bayi kelihatan } \\
\text { lemas }\end{array}$ & & & Valid \\
\hline & $\begin{array}{l}\text { Mulut dan bibir } \\
\text { pecah pecah }\end{array}$ & & & Valid \\
\hline \multirow{6}{*}{2.} & $\begin{array}{l}\text { Bayi kelihatan } \\
\text { lemas }\end{array}$ & \multirow[t]{6}{*}{$\begin{array}{c}\text { Campak } \\
96 \%\end{array}$} & \multirow[t]{6}{*}{$\begin{array}{l}\text { Campak } \\
80-90 \%\end{array}$} & Valid \\
\hline & Bayi demam & & & Valid \\
\hline & $\begin{array}{l}\text { Ruam kemerahan di } \\
\text { wajah }\end{array}$ & & & Valid \\
\hline & $\begin{array}{l}\text { Bintik putih pada } \\
\text { area mulut }\end{array}$ & & & Valid \\
\hline & $\begin{array}{l}\text { Mata merah dan } \\
\text { sensitif terhadap } \\
\text { cahaya }\end{array}$ & & & Valid \\
\hline & $\begin{array}{l}\text { Nafsu makan } \\
\text { menurun }\end{array}$ & & & Valid \\
\hline \multirow{3}{*}{3.} & $\begin{array}{l}\text { Bercak kemerahan } \\
\text { pada bagian area } \\
\text { bokong, paha dan } \\
\text { alat kelamin }\end{array}$ & \multirow[t]{3}{*}{$\begin{array}{c}\text { Ruam } \\
\text { Popok } \\
96 \%\end{array}$} & \multirow[t]{3}{*}{$\begin{array}{l}\text { Ruam } \\
\text { Popok } \\
80-90 \%\end{array}$} & Valid \\
\hline & Bayi menjadi rewel & & & Valid \\
\hline & $\begin{array}{l}\text { Kulit bayi terasa } \\
\text { panas saat disentuh }\end{array}$ & & & Valid \\
\hline \multirow{2}{*}{4.} & $\begin{array}{l}\text { Nafsu makan } \\
\text { menurun }\end{array}$ & \multirow[t]{2}{*}{$\begin{array}{c}\text { Demam } \\
89 \%\end{array}$} & \multirow[t]{2}{*}{$\begin{array}{l}\text { Demam } \\
80-90 \%\end{array}$} & Valid \\
\hline & $\begin{array}{l}\text { Suhu tubuh bayi } \\
\text { diatas } 37,6\end{array}$ & & & Valid \\
\hline
\end{tabular}




\begin{tabular}{|c|c|c|c|c|}
\hline & Bayi menjadi rewel & & & Valid \\
\hline & Muntah-muntah & & & Valid \\
\hline & $\begin{array}{l}\text { Bayi kelihatan } \\
\text { lemas }\end{array}$ & & & Valid \\
\hline \multirow{5}{*}{5.} & Batuk- batuk & \multirow[t]{5}{*}{$\begin{array}{c}\text { Batuk Pilek } \\
97 \%\end{array}$} & \multirow{5}{*}{$\begin{array}{c}\text { Batuk } \\
\text { Pilek } \\
80-90 \%\end{array}$} & Valid \\
\hline & $\begin{array}{l}\text { Hidung bayi meler } \\
\text { atau tersumbat }\end{array}$ & & & Valid \\
\hline & Bayi menjadi rewel & & & Valid \\
\hline & Bayi demam & & & Valid \\
\hline & $\begin{array}{l}\text { Bayi kelihatan } \\
\text { lemas }\end{array}$ & & & Valid \\
\hline \multirow{3}{*}{6} & $\begin{array}{l}\text { Bintik kemerahan } \\
\text { pada kulit bayi }\end{array}$ & \multirow[t]{3}{*}{$\begin{array}{l}\text { Dermatitis } \\
\quad 96 \%\end{array}$} & \multirow[t]{3}{*}{$\begin{array}{l}\text { Dermatitis } \\
80-90 \%\end{array}$} & Valid \\
\hline & Bayi menjadi rewel & & & Valid \\
\hline & Gatal- gatal & & & Valid \\
\hline
\end{tabular}

Berdasarkan hasil pengujian dengan pakar, dapat diketahui kesesuaian pengujian antara hasil dari seorang pakar dengan sistem pakar diagnosis penyakit pada bayi dengan penerapan dempster shafer menghasilkan output yang sama, sehingga aplikasi yang telah dibuat dapat digunakan untuk mendiagnosis penyakit pada bayi serta mendapatkan informasi seputar kesehatan bayi.

\section{Kesimpulan}

1. Sistem pakar yang dibuat dapat memberikan alat bantu bagi masyarakat terutama orang tua dalam mendiagnosa gangguan penyakit pada bayi dan mendapatkan informasi asupan makanan sesuai kebutuhan bayi.

3. Kesesuaian pengujian dengan melakukan perbandingan hasil output antara pakar dengan sistem pakar yang dibuat.

4. Aplikasi ini menggunakan teknologi mobile yaitu android. Android dipilih untuk memudahkan orang mengaksesnya dan bisa langsung menerapkannya.

\section{Referensi}

Ayu, A., \& Hasibuan, N. A. (2017). Diagnosa Penyakit Sepsis. I, 154-160.

Hafizh, M., \& Putra, T. A. (2018). Implementasi Metode Dempster Shafer Pada Sistem Pakar Diagnosis Penyakit Ginjal Berbasis Web Dengan Menggunakan Php Dan Mysql. Indonesian Journal of Computer Science, $\quad 7(2), \quad$ 143-152. https://doi.org/10.33022/ijcs.v7i2.87
Hasibuan, P. S., \& Batubara, M. I. (2019). Penerapan Metode Dempster Shafer Dalam Mendiagnosa Penyakit Faringitis. Jurnal Media Informatika Budidarma, 3(1), 59. https://doi.org/10.30865/mib.v3i1.1061

Kanggeraldo, J., Sari, R. P., \& Zu, M. I. (2018). Sistem Pakar Untuk Mendiagnosis Penyakit Stroke Hemoragik dan Iskemik Menggunakan Metode Dempster Shafer. Jurnal RESTI (Rekayasa Sistem Dan Teknologi Informasi), 2(2), 498-505. https://doi.org/10.29207/resti.v2i2.268

Mubarok, A., Susanti, S., \& Imelia, N. (2020). Aplikasi Sistem Pakar Diagnosis Gangguan Gizi Pada Anak Menggunakan Metode Dempster Shafer. JURNAL RESPONSIF: Riset Sains \& Informatika, 2(1), 53-64.

Syaifuddin, M., Honggowibowo, A. S., Informatika, J. T., Tinggi, S., \& Adisutjipto, T. (2014). Sistem Pakar Diagnosa Penyakit Bayi dan Balita Berbasis Android Dengan Menggunakan Algoritma. 27-32.

Utama, Y. A. K., \& Hidayat, D. T. (2020). Desain Metode PID-Simulated Annealing Sebagai Kontrol Temperatur Pada Inkubator Bayi. Jurnal Elektro, 5(1), 341-347.

Wulandari, D. A., Hadri, I., Program, U., \& Negara, S. A. (2018). Responsivitas Dinas Kesehatan Kabupaten Karanganyar dalam Upaya Menurunkan Angka Kematian Ibu (AKI) dan Angka Kematian Bayi (AKB) di Kabupaten Karanganyar. In Jurnal Wacana Publik (Vol. 1, Issue 3). https://jurnal.uns.ac.id/wacanapublik/article/view/18006 